\title{
The Impact of Waste Management in the Macroeconomic Performance
}

\author{
Prof.Assoc.Dr .Doriana Matraku (Dervishi) \\ Adela Çafuli PhD Cand.
}

Abstract

\begin{abstract}
Public attention to solid waste management has increased dramatically over the past decade in Europe because of the fact that the economic development has had its impact in consume. This increase in consume has affected to the production of different waste and therefore the necessity to manage them through different necessary policies of each country. Currently, Albania is a potential candidate country to be part of European Union. With the assignment of the Stabilization-Association Agreement, in 2006, the government undertook a series of commitments, where some of them are relative to taking into consideration the environment values during the decision-making process, in line with the sixth Action Program for the Environment, 2002. This paper provides an overview of recent trends in solid waste and management and the related public policy issues, in some cases combined with the economics literature related to this issues, in Europe and in particular in Albania. The main issues that will be treated in this paper are the public policies in Albania for solid waste and management. Is Albania completely ready for their management or not yet? The first part of this paper will give a theoretical overview of solid waste and of the ways used for their management as well as the economics literature related to the issues of the paper. A literature review will describe the recent trends in solid waste in some of the countries of European Union that have undertaken a lot of waste management policies and that have taken economic profit from this industry. The second part of the paper will focus in the Albanian case. Taking into consideration that Albania is a potential country to be integrated to European Union, we have commitment to complete also the waste management, in the framework of environmental issues. Also a very important part will focus in the impact of this issue to GDP growth of the country. In the end we will focus in some conclusions and also in recommendations about these important issues.
\end{abstract}

Keywords:solid waste management, macroeconomic indicators, public policies, GDP growth.

\section{INTRODUCTION}

Increase of consume as an effect of economic developments despite the financial crisis, has affected the production of different waste and therefore increasing the necessity to manage them through different policies in different coutries in Europe. This is an issue that affects all people around the world, independent from origin, ethnicity, color and faith. Altogether, the European Union produces up to 6 billion tonnes of waste every year (Eurostat, 2015). This amount has its impact on the environment, to say a huge impact on it, as well as in economy. Nowadays, we are creating a large amount of complex mix waste including plastics, precious metals and hazardous materials.

This article gives a theoretical overview of solid waste and solid waste management in general as well as recent trends of solid waste and their management in European Union. The second part gives an overview of solid waste management in Albania, the third part gives some evidences of how solid waste management has affected the macroeconomic performance. The last part gives some conclusions and recommendations.

\section{THEORITICAL OVERWIEW OF WASTE, WASTE MANAGEMENT AND RECENT TRENDS IN EUROPEAN UNION}

This section gives a theoretical overview of solid waste and solid waste management in general as well as recent trends of solid waste and their management in European Union.

\subsection{Theoritical overwiew of waste and waste management}

\section{Definitions and classifications}

The first Framework Directive on Waste (75/442/EEC) in 1975 gave the first definition of "waste". Its Article 1 defines waste as "any substance or object which the holder disposes or is required to dispose of pursuant to the provisions of national law in force". Defined in that manner, lead to different definitions of waste in each Member State, a situation that 
changed in 1991 with the revised Framework Directive on Waste(WDF) (91/156/EEC) .According to this WDF as well as Directive 2008/98/EC waste is defined to as 'any substance or object which the holder discards or intends or is required to discard'. Solid waste is the material generated from various human activities and which is normally disposed as useless and unwanted.

\section{Classification of solid waste:}

- $\quad$ municipal waste : includes waste resulting from municipal activities and services such as street wastes, dead animals, market wastes and abandoned vehicles;

- $\quad$ residential waste: solid wastes that originate from single and multi-family house hold units. These wastes are generated as a consequence of house hold activities such as cooking, cleaning, repairs, hobbies, redecoration, empty containers packaging, clothing, old books, paper and old furnishings;

- commercial waste: included in this category are solid wastes that originate in offices, wholesale and retail stores, restaurants, hotels, markets, warehouses and other commercial establishments;

- garbage: term applied to animal and vegetable waste resulting from the handling, storage, sale, cooking and serving food;

- $\quad$ rubbish: is general term applied to solid wastes originating in households, commercial establishments and institutions, excluding garbage \& ashe;

- $\quad$ institutional waste arise from institutions such as schools, universities, hospitals and research institutes. It includes wastes, which are classified as garbage and rubbish, as well as wastes, which are considered to be hazardous to public health and to the environment;

- $\quad$ ashes: are the residues from the burning of wood, coal, charcoal, coke and other combustible materials for cooking and heating in houses, institutions and small industrial establishments;

- bulky wastes: bulky household wastes, which can't be accommodated in the normal storage containers of households. For this reason they require special collection;

- $\quad$ street sweeping: applies to wastes that are collected from streets, walkways, alleys, parks and vacant lots;

- dead animals: applied to dead animals that die naturally or accidentally killed;

- construction and demolition wastes: are the waste materials generated by the construction, refurbishment, repair and demolition of houses, commercial buildings and other structures;

- $\quad$ industrial Wastes: are the discarded solid material of manufacturing processes and industrial operations;

- $\quad$ hazardous wastes may be defined as wastes of industrial, institutional or consumer origin which because of their physical, chemical or biological characteristics are potentially dangerous to human and the environment. In some cases although the active agents may be liquid or gaseous, they are classified as solid waste because they are confined in solid containers;

- $\quad$ sewage wastes : the solid by-products of sewage treatment;

- $\quad$ biomedical/hospital waste: is generated during the diagnosis, treatment, or immunization of human beings or animals or in research activities in these fields or in the production or testing of biological;

- plastics.

\section{Waste management}

According to Wikipedia, Waste managementis the "generation, prevention, characterization, monitoring, treatment, handling, reuse and residual disposition of solid wastes". There are various types of solid waste including municipal (residential, institutional, commercial), agricultural, and special (health care, household hazardous wastes, sewage sludge)." Waste management constitutes a procedure that should preserve sustainability, while the efficiency of the technologies should in any case insure social acceptance, environmental protection and economic viability (Marconsin \& Rosa, 2013; Hanan et al 2013; Morrissey \& Browne, 2004). 


\section{Waste legislation}

Waste management is largely regulated by legislation and policy implemented at the municipal level:

The Waste Framework Directive, revised in 2008, streamlines waste legislation, incorporating rules on a number of issues such as themanagement of hazardous waste and waste oils.

Other pieces of EU waste legislation:

- The Regulation on waste shipments aims to ensure the safe shipment of all types of waste, including hazardous waste;

- The Packaging and Packaging Waste Directive sets standards for the design of packaging and lays down specific targets for the recycling and recovery of waste packaging;

- The EU's Landfi II Directive and the Waste Incineration Directive set standards and limits for the release of pollution into the air or into groundwater;

- The End-of-Life Vehicles Directive sets rising re-use, recycling and recovery targets and restricts the use of hazardous substances in both new vehicles and replacement vehicle parts;

- Waste Electrical and Electronic Equipment (WEEE) legislation lays down collection, recycling and recovery targets for electrical goods;

- The Directive on the Restriction of Hazardous Substances in electrical and electronic equipment restricts the use of hazardous substances in electronics;

- The Batteries Directive sets collection, recycling and recovery targets, thereby ensuring their proper waste management;

- Legislation also targets specific waste streams such as sewage sludge, batteries, polychlorinated biphenyls and polychlorinated terphenyls (PCBs/PCTs).

\section{Methods of Waste Disposal:}

-Landfill: is the most common used method of waste disposal and it mainly consists on burying the waste in the land. It eliminates the waste odors and dangers before placing them into the ground. But we are facing with the lack of space available to use landfills. The Landfill Directive obliges Member States to reduce the amount of biodegradable waste they landfill to $35 \%$ of 1995 levels by 2016 , which will significantly reduce the problem of methane production. In addition, methane gas must be collected in landfill sites and, if possible, used to produce energy. EU legislation on landfilling is making a big difference. Thousands of sub-standard landfill sites have been closed across Europe and the amount of municipal waste put into landfills in the EU has fallen by more than 25\% since 1995.

-Incineration/Combustion: is a method in which municipal solid wastes are burned at high temperatures so as as to convert them into residue and gaseous products. This process is also known as thermal treatment where solid waste materials are converted by Incinerators into heat, gas, steam and ash. Incineration is something that is very in countries where landfill space is no longer available.

-Recovery and Recycling: Recovery is the process of taking useful discarded items for a specific next use. Recycling is the process of converting waste products into new products to prevent energy usage and consumption of fresh raw materials. Recycling is the third component of Reduce, Reuse and Recycle waste hierarchy.

\subsection{Recent trends of waste management in European Union}

Waste represents an enormous loss of resources such as materials and energy. Managing and disposing them can lead to serious impacts in environment. Even though, countries of European Union continue to improve ways of managing waste, they still lose a significant amount of metals, wood, glass, paper, plastics. According to Eurostat, people in European Union use 16 tonnes of material per person per year, 6 tonnes of which become waste. 
Nowadays, European Union waste management policies aim to reduce problems caused in environment and health of waste generation and the long term goal is to avoid waste and use aunavoidable waste as e resource. The target is to recycle more and to ensure resource efficiency and the sustainable growth of European economies.

European Union objectives:

- To reduce the amount of waste generated;

- $\quad$ To maximise recycling and re-use;

- To limit incineration to non-recyclable materials;

- $\quad$ To phase out landfilling to non-recyclable and non-recoverable waste;

- $\quad$ To ensure full implementation of the waste policy targets in all Member States.

\section{Waste generation in European Countries}

Main amount of waste in European Countries are generated from activities such as: Mining and quarrying, Manufacturing, Energy, Construction, Other Economic activities and households.

According to data of Eurostat, April 2015, in 2012, the total waste generated in the EU-28 by all economic activities and households amounted to 2515 million tonnes; slightly higher than in 2010 and 2008 (2 460 million tonnes and 2427 million tonnes) but lower than in 2004(2 565 million tonnes); this is as a result of the financial and economic crisis. As shown in Table 1, there were considerable variations across EU-28 Member States in 2012, both in the amount of waste generated and in the activities that mostly contributed to waste generation(Eurostat, 2015)

$63 \%$ of the total waste generates in European Union was mineral waste. Member States that had higher shares of mineral waste were those countries that were characterized as having sizeable mining and quarrying activities. These countries are Bulgaria, Finland, Estonia, Sweden and Romania and / or construction and demolition activities such as Luxembourg. These two activities accounted for 3.0 tonnes out of a total of 3.2 tonnes per inhabitant of mineral waste, equivalent to $93.5 \%$ of the total mineral waste generated across the European Union in 2012.

\begin{tabular}{|c|c|c|c|c|c|c|c|}
\hline Country & Total & $\begin{array}{r}\text { Mining and } \\
\text { quarrying }\end{array}$ & $\begin{array}{r}\text { Manufactu } \\
\text { ring }\end{array}$ & Energy & Construction & $\begin{array}{r}\text { Other } \\
\text { economic } \\
\text { activities }\end{array}$ & Households \\
\hline Belgium & 67630 & 115 & 17736 & 1314 & 24570 & 18891 & 5004 \\
\hline Bulgaria & 161252 & 141083 & 3009 & 9533 & 1033 & 3841 & 2755 \\
\hline $\begin{array}{l}\text { Czech } \\
\text { Republic }\end{array}$ & 23171 & 167 & 4376 & 1063 & 8593 & 5739 & 3233 \\
\hline Denmark & 16332 & 18 & 1610 & 893 & 3867 & 6216 & 3727 \\
\hline Germany & 368022 & 8625 & 56596 & 8050 & 197528 & 60752 & 36472 \\
\hline Estonia & 21992 & 9355 & 4121 & 6258 & 657 & 1156 & 436 \\
\hline Ireland & 13421 & 2025 & 4599 & 396 & 366 & 4379 & 1657 \\
\hline Greece & 72328 & 47832 & 4183 & 12259 & 813 & 2383 & 4859 \\
\hline Spain & 118562 & 22509 & 14594 & 5772 & 26129 & 28333 & 21224 \\
\hline France & 344732 & 2477 & 21431 & 2100 & 246702 & 42024 & 29996 \\
\hline Croatia & 3379 & 5 & 425 & 108 & 682 & 968 & 1191 \\
\hline
\end{tabular}




\begin{tabular}{|c|c|c|c|c|c|c|c|}
\hline Italy & 162765 & 720 & 34142 & 3615 & 52966 & 41708 & 29613 \\
\hline Cyprus & 2086 & 218 & 98 & 2 & 965 & 353 & 451 \\
\hline Latvia & 2310 & 2 & 396 & 133 & 8 & 558 & 1213 \\
\hline Lithuania & 5679 & 26 & 2551 & 29 & 419 & 1477 & 1177 \\
\hline Luxembourg & 8397 & 131 & 509 & 2 & 7079 & 426 & 249 \\
\hline Hungary & 16310 & 91 & 2991 & 2872 & 4038 & 3638 & 8681 \\
\hline Malta & 1452 & 45 & 9 & 2 & 1041 & 201 & 155 \\
\hline Netherlands & 123613 & 179 & 14115 & 1342 & 81354 & 17758 & 8854 \\
\hline Austria & 34047 & 51 & 3636 & 622 & 19471 & 6247 & 4020 \\
\hline Poland & 163378 & 68035 & 31135 & 20706 & 15368 & 18809 & 9324 \\
\hline Portugal & 14184 & 243 & 3188 & 422 & 928 & 4672 & 4731 \\
\hline Romania & 266796 & 223293 & 6029 & 9043 & 1325 & 22638 & 4647 \\
\hline Slovenia & 4547 & 14 & 1345 & 1069 & 535 & 941 & 641 \\
\hline Slovakia & 8425 & 311 & 2516 & 1046 & 806 & 2090 & 1657 \\
\hline Finland & 91824 & 52880 & 14531 & 1011 & 16034 & 5635 & 1734 \\
\hline Sweden & 156367 & 129481 & 6218 & 1852 & 7656 & 6967 & 4193 \\
\hline $\begin{array}{l}\text { United } \\
\text { Kingdom }\end{array}$ & 241922 & 24044 & 13596 & 4965 & 100230 & 71580 & 27506 \\
\hline Total & 2515110 & 733980 & 269690 & 96480 & 821160 & 380390 & 213410 \\
\hline
\end{tabular}

Table 1. Waste generation by economic activities and households in European Union for 2012(thousand tones)

Source: Eurostat, April 2015

\section{Waste management in some Member States of European Union}

Waste management in European Union is based on:

- $\quad$ waste prevention;

- $\quad$ recycling and reuse: waste that cannot be recycled or reused should be safely incinerated with landfills, used only as a last resort;

- $\quad$ improving final disposal and monitoring.

All these methods need monitoring in order not to cause several environmental problems.

Eurostat collects under the Waste Statistics Regulation comprehensive data on waste generation and treatment from EU Member States and European Economic Area countries. After the fifth report in June 2014, data are available for the period 2004-2012. The Waste Statistics Regulation data are increasingly used as a basis for indicators to monitor waste generation and management in the EU'

1 The sustainable development indicators are part of a set of indicators used to monitor the EU sustainable development strategy. This strategy and its seventh environment action programme - the General Union Environment Action 
In 2010, total waste production in the EU amounted to 2,5 billion tons. From this total only a limited (albeit increasing) share $(36 \%)$ was recycled, with the rest was landfilled or burned, of which some 600 million tons could be recycled or reused. In 2012, some 2303 million tonnes of waste were treated in the EU-28; this includes the treatment of waste imported into the EU and the reported amounts are therefore not directly comparable with those on waste generation(Eurostat, 2015).

This paper will give an overview of waste management in some of the countries , member state of European Union such as Bulgaria, Poland, Slovenia and Romania with data of 2012 taken from Eurostat.

Table 2 shows more information regarding the types of waste treatment operation such as : Recycling, Energy Recovery, Backfilling (is the use of waste in excavated areas for the purpose of slope reclamation or safety or for engineering purposes in landscaping)., Incineration, Landiflling. Significant differences could be observed among these European Union Member States concerning the use they made of the various treatment methods. For instance, some Member States had very high recovery (other than energy recovery) rates such as Slovenia and Poland, while others favored waste disposal such as Bulgaria and Romania.

Table 2. Waste treatment in Bulgaria, Poland, Slovenia and Romania, 2012 (in million tones)

\begin{tabular}{|l|l|l|l|l|l|l|}
\hline Country & Recycling & $\begin{array}{l}\text { Energy } \\
\text { Recovery }\end{array}$ & Backfilling & Incineration & Landfilling & Total \\
\hline Bulgaria & 61 & 0 & 0 & 5 & 13323 & 13390 \\
\hline Poland & 1158 & 2 & 0 & 143 & 132 & 1435 \\
\hline Slovenia & 48 & 5 & 1 & 9 & 13 & 75 \\
\hline Romania & 116 & 166 & 0 & 136 & 103 & 521 \\
\hline
\end{tabular}

\section{Source: Eurostat, April 2015}

\section{Bulgaria}

From the table, it can be seen that in Bulgaria more amount of waste are landfilled rather than using recycling, energy recovery, backfilling and incineration. It has also the great amount of waste treated. Bulgaria is among the member-states with close to the average level of recycling in recent years. The reasons are the insufficient facilities for recovery of biodegradable municipal waste. From table 1 , we can see that the great amount of waste is generated from mining and quarrying.

The waste management policy and legislation in Bulgaria aims at implementing the relevant EU directives, regulations and decisions in this field. National framework is built in the changes in European waste legislation which aims even higher level of protection of the environment and human health, as well as the transition from waste management to sustainable management and efficient use of resources. According to this it is expected:

Programme to 2020 'Living well, within the limits of our planet' (Decision No 1386/2013/EU) — set the objectives, amongst others, of turning Europe into a resource-efficient, green, competitive, low-carbon economy. The intention of EU policy in this area is to further tackle the unsustainable and inefficient use of resources and to improve waste prevention and management. These issues were addressed in the evaluation of the thematic strategy on the prevention and recycling of waste (COM(2011) 13 final) and the final assessment of the Sixth Community Environment Action Programme (COM(2011) 531 final). 
- to have additional restrictions for landfill of waste;

- $\quad$ specific provisions for reduce consumption and prevent waste from polythene;

- $\quad$ restrictions for incinerators of waste which can be recycled;

- introduction of higher recycling targets for municipal waste, especially for plastic waste,

- $\quad$ introduction of quantitative targets for waste prevention, especially for plastic, municipal /food and hazardous waste;

- $\quad$ higher goals for preparation for reuse and recycling of packaging waste.

Land filling remains the main method of waste disposal in the country. Construction waste Bulgaria has prepared a strategic plan for management of construction waste for the period until 2020, where specific targets for reuse, recycling and recovery of construction waste were set. The amount of construction waste generated is reduced in recent years. The majority of construction waste has a high potential for recycling and recovery. There will be a beneficial impact from increasing the capacity of the competent authorities by providing appropriate training including presentation of good practices of other EU member-states in issuing permits for production target groups for Bulgaria in terms of the hierarchy of waste management. Projects of scientific-research teams and businesses for studying and solving specific problems on hazardous waste should be supported under Priority Axis "Technology Development and Innovation" of Operational Programme "Competitiveness and Innovation 2014-2020".

\section{Poland}

Poland is the second state that has the great amount of waste treated after Bulgaria. The amount of waste recycled is bigger than waste treated with energy recovery, backfilling, incineration and landfilling. From table 1, we can see that the greater amount of waste is generated from mining and quarrying as well as Bulgaria. According to Eurostat, a growth of municipal waste has been observed from 2009-2012 but its rate has been far below the rate of growth in consumption.

The first Polish law concerning waste management came into force on 1 January 1998 and another important act regarding cleanliness and order in municipalities came into force on 1 January 1997. The main piece of legislation relating to waste management is the 27 April 2001 Act on Waste(Journal of Laws 2007 No. 39, item 251, with amendments). There have been three National Waste Management Plans. The latest National Waste Management Plan, adopted in December 2010, sets objectives and tasks for the period 2011-2014 and outlines perspectives for 2015-2022. These objectives include:

- $\quad$ increasing the percentage of recovery (especially the recycling of glass, metals, plastics and paper);

- favouring the practical application of the waste management hierarchy;

- $\quad$ and minimising the storage of waste.

\section{Romania}

Romania, is the third country with the large amount of waste treated where the amount treated with energy recovery is greater than the other amount of waste treated. From table 1 we can see that the greater amount of waste is generated from mining and quarrying.

There are several strategy documents in place, including the National Waste Management Strategy, the National Waste Management Plan (developed in 2004), the Regional Waste Management Plans for the eight Romanian regions (issued in 2006) and the Report on Environmental Quality in Romania. There are also regulations for municipal, hazardous and nonhazardous waste, and packaging waste. The development of the legal framework is only part of the solution for the problems that Romania faces in terms of waste management. It is also necessary to foster private sector investment in waste management infrastructure, strengthen the authorities' ability to enforce waste legislation and develop waste charging systems. 
By 2020, Law 211/2011 aims to re-use and recycle at least $50 \%$ of the overall weight of domestic waste and at least $70 \%$ of the weight of non-hazardous waste produced from construction and demolition activities(reference)

Romania has also transposed the Landfill Directive into national legislation through Government Decision 349/2005.67 There are transitional periods for full compliance with certain types of landfills: 2013 for non-hazardous industrial waste; and 2017 for municipal landfills.

\section{Slovenia}

And the last is Slovenia with the great amount of waste recycled. Waste management in Slovenia is mostly based on the Environment Protection Act (adopted in 2004), the Decree on the Land filling of Waste (adopted in 2006), the Decree on Waste (adopted in 2011), Regulation (EC) No. 1013/2006 on Shipments of Waste and the Decree on the Implementation of Regulation (EC) No. 1013/2006 on Shipments of Waste. Environment targets for waste management in Slovenia have been harmonized with the EU targets. The volume of waste generated in Slovenia is growing annually, with more than 7 million tones of waste being generated each year. The recovery of waste is improving.

\section{SOLID WASTE MANAGEMENT IN ALBANIA}

Albania is a potential candidate country to be part of European Union. With the assignment of the Stabilization-Association Agreement, in 2006, the government undertook a series of commitments, where some of them are relative to taking into consideration the environment values during the decision-making process, in line with the sixth Action Program for the Environment, 2002. Therefore, Albania has recently adopted laws in compliance with the European norms and legislation.

\subsection{Legislation framework}

Current legislation on this issue:

- Law no.10 431, 9.6.2011 "On the protection of environment";

- Law no.10 463, 22.9. 2011 "On the integrated waste management "which transposes the Waste Framework Directive (2008/98/EC);

- $\quad$ DCM No. 798, date 29.09.2010 "On the approval of the regulation "On the hospital waste management";

- DCM No. 175, date 19.1.2011 "On the approval of the National Waste Management Strategy and National Waste Management Plan";

- DCM No. 178, dated 6.3.2012 "On incineration of waste" ;

- DCM No. 52, dated 11.7.2012 "On landfill of waste";

- DCM No. 177, dated 6.3.2012 "On packaging and their waste" ;

- $\quad$ DCM No. 866, dated 4.12.2012 "On batteries, accumulators and their waste" ;

- $\quad$ DCM No. 705, dated 10.10.2012 "On the administration of End of Life Vehicles ;

- DCM No. 765, dated 7.11.2012 "On the approval of rules on separated collection and treatment of used oils" 5. n/a 6. n/a 7;

- $\quad$ In process 4 regional plans: Gjirokastër, Kukës, Berat, Fier. This plan includes the period $2012-2025$.

\subsection{Current situation and the National Plan of waste management 2010-2025}

Solid waste administration in Albania is currently decentralized and mostly municipal. In the main part of the cities, accumulation and transportation of waste to landfills, most of the time not conform to the norms, is made by private companies contracted from municipalities. The rural areas are not yet covered by waste management services and they deposit a large amount of waste in rivers or in the streets. As a conclusion, the responsibility for urban waste collection lies with the local authorities. Two thirds of the municipalities contract private companies withpublic tender and their contracts are of 3-5 year duration(UNECE, 2012). The collected waste is transported without pre tratement to landfills or disposal 
sites. There are constructed some landfills complying with environmental standarts in some regions, in others they are still in process of contruction or commissioned.

The level of waste generation is low in comparison to other European Countries and the current level of waste management especially municipal waste management( as the main part of waste in Albania are municipal) is at a low level. The volume of MSW in Albania has been steadily increasing in recent years. So MSW generated in total is about 825.000 tons/year (2012) or about $266 \mathrm{~kg} / \mathrm{capita} / \mathrm{year}$, from which the organic matter in nationally level constitutes $47,36 \%$ and in total the percentage of biodegradable matter is about 62,3\% [2], and in 2013 is 1.039 .455 tons MSW and the amount of inert waste is 293.361 tons(International Journal of Science Technology \& Management, Volume No.04, Special Issue No.01, February 2015).

Table 3. Waste generation according to districts in Albania for the year 2013

\begin{tabular}{|l|l|l|l|l|}
\hline District & Population & $\begin{array}{l}\text { Annual amount } \\
\text { Tons/capita }\end{array}$ & $\begin{array}{l}\text { Annual amount } \\
\text { Urban waste /tons }\end{array}$ & $\begin{array}{l}\text { Annual amount } \\
\text { Solid waste/tons }\end{array}$ \\
\hline Berat & 230764 & 0.209 & 48353 & 18050 \\
\hline Diber & 177974 & 0.186 & 33178 & 16080 \\
\hline Durres & 282600 & 0.191 & 54129 & 4597 \\
\hline Elbasan & 285878 & 0.239 & 68461 & 28900 \\
\hline Fier & 501002 & 0.325 & 163214 & 14566 \\
\hline Gjirokaster & 103732 & 0.364 & 37862 & 44672 \\
\hline Korca & 376562 & 0.206 & 77846 & 8162 \\
\hline Kukes & 116061 & 0.148 & 17232 & 6700 \\
\hline Lezha & 210748 & 0.312 & 65910 & 15945 \\
\hline Shkodra & 339072 & 0.195 & 66453 & 12510.5 \\
\hline Tirana & 1030508 & 0.328 & 308926 & 48751 \\
\hline Vlora & 368514 & 0.265 & 97891 & 74432 \\
\hline Total & 4023415 & 0.224 & 1039455 & 293360.5 \\
\hline
\end{tabular}

\section{Source : Ministry of Transport and Infrastructure}

As it is seen from the table 3, District of Tirana generates the greatest amount of urban waste, District of Vlora generates the greatest amount of solid waste. This is explained by the large number of population and the economic development.

The implementation of National Waste Strategy and the National Waste Management Plan 2010-1025 has made some improvements. Within this National Waste Mangament Plan, Albania has started the development of new regional landfills, in compliance with the EU environmental and sanitary standarts of European Union. Local waste management plans focus on the collection of waste, including waste separation and recycling arrangements. In order to best manage waste at a strategic level in Albania, the country has been split into 12 waste areas, based on the geographical boundaries of the existing regional administrative districts. In addition, the affairs of these waste areas will be managed by an overarching body - the 'Waste Area Group' - consisting of local and regional stakeholders. Based on the implementation of the National Strategy and Plan for waste management in Albania, new landfills have been constructed and a few more are in the planning process. 
Situation of current regional landfills:

- Solid waste management of Tirana(Sharra)

- Landfill of Shkodra, Bushat

- Landfill Rreshen

- Landfill Bajram Curri

- Landfill Korca

- $\quad$ Landfill Bakaj, Saranda

NWMP 2010-2025 consists on 3 operational phases of 5 years each. The objectives are:

- Recycle/compost $25 \%$ of municipal solid waste by 2015

- $\quad$ Stop the increase of municipal waste produced

- Recycle/compost $55 \%$ of municipal solid waste by 2020

- Reclamation of energy from $15 \%$ of municipal waste by 2025

These objectives will be implemented through:

- The national Waste Plan: To increase the amount of waste collected by local authorities that is recycled/composted to $25 \%$ by 2015 , to increase the amount of waste collected by local authorities that is recycled /composted to $55 \%$ by 2020 ;

- The regional Waste Managament plans;

- The local waste management plans.

Tha main target is a change in the practices used until now for waste management, It is aimed to reduce landfilling to $30 \%$, with $70 \%$ recovery by recycling/composting/conversion to energy.

\section{IMPACT OF SOLID WASTE MANAGEMENT IN MACROECONOMIC PERFORMANCE}

There exists a close relation between economy and environment. The waste sector rather than having negative environment impact, it needs also to contribute to the economic sustainability, by opening new enterprises, therefore new and more jobs but also cost savings for waste disposal by minimizing the amount of residual waste. In order that waste management have positive contribution to the economy it needs funds and investments for infrastrcutre, services as well as equipment. The costs to provide waste management services typically amounts to around 3-15\% of a city's budget or 0.1 to $0.7 \%$ of per capita GDP( International Solid Waste Association, June 2013). If there would be no effective ways to manage waste the impact of this in economy would be negative. European Union is aiming to become a "recycling society" by supporting a greener economy. This means more efficiency and improved security of supply ( given by the Europe 2020 Strategy adopted by the European Council in June 2010). Over the past few decades the amount of solid waste has grown alongside growth in Gross Domestic Product (GDP). Waste management presents an opportunity, not only to avoid the detrimental impacts associated with waste, but also to recover resources, realise environmental, economic and social benefits and to take a step on the road to a sustainable future.

The selection of the applicable waste treatment method among the variety of technologies should take into consideration local market characteristics and the existence of potential off-takers in the vicinity of the facilities, in order to enhance the feasibility of investments (Rentizelas et al. 2014), as well as to minimize environmental burdens (Andrea 2015). Investing in waste management is expected to generate economic, social and environmental benefits such as :

natural resource and energy saving;

creation of new businesses and jobs affecting gdp growth;

compost production supporting organic agriculture; 
energy production from waste;

reduced GHG emissions;

contributions to equity and poverty eradication.

Regarding job creation, workers working in this serctor wether formally employed or self employed are the agents of change as they have great values in climate policies and social value-added. The most important sector in creating employment is recycling. This sector creates a source of income for workers who have poor background or low levels of education. The pollution from many belowstandard waste treatment and disposal facilities directly impact populations living close to these facilities. It has been observed that hazardous waste dumps and incinerators are mostly located in the poorest neighbourhoods, both in developed and developing countries (Wapner 2002). Inv esting includes considerations of these equity and poverty issues. Investing in greening the sector is not only about building facilities; it also includes the formalisation of the sector so that workers receive training, health protection and benefits, and a fair compensation for their labour.

Regarding Albania, according to the National Plan of Solid Waste Management 2010-2025, the building of 12 regional landfills will cause profits from the economies of scale. According to this plan, the municipalities that will manage waste can cooperate together, and this will lead to the fact of reducing individual costs as well as to have an increase higher service standarts. Inv esting in these landfills in Albania should create opportunities fro new jobs in this country and therefore increase the welfare of the people, increase consume by increasing as well as the GDP of the country.

\section{CONCLUSIONS AND RECOMMANDATIONS}

Nowadays, European Union waste management policies aim to reduce problems caused in environment and health of waste generation and the long term goal is to avoid waste and use aunavoidable waste as e resource. Some Member States had very high recovery (other than energy recovery) rates such as Slovenia and Poland, while others favored waste disposal such as Bulgaria and Romania. Solid waste administration in Albania is currently decentralized and mostly municipal. The implementation of National Waste Strategy and the National Waste Management Plan 2010-1025 has made some improvements. Within this National Waste Mangament Plan, Albania has started the development of new regional landfills, in compliance with the EU environmental and sanitary standarts of European Union. In general, waste management has improved. The waste sector rather than having negative environment impact, it needs also to contribute to the economic sustainability, by opening new enterprises, therefore new and more jobs but also cost savings for waste disposal by minimizing the amount of residual waste.

What is needed:

- $\quad$ additional national and regional instruments are necessary to achieve targets;

- $\quad$ plans need to be complemented with additional initiatives to establish better recycling infrastructure or divert waste away from landfills;

- the way in which policy instruments are combined may be more relevant than the total number of instruments;

Recommandations for Albania:

- Implementation of Waste Management Plan 2010-2025

- Creating administrative structure in national and local level

- Enhancement of the public for selecting and accumulating urban waste

- $\quad$ Fostering the cooperation between local authoritu, interest groups, civil society, private bussinesses 
- Ensuring full information from experts regarding waste management

- Implementing different projects of low cost

\section{References}

[1] Albania, 2009: 'National Plan on Waste Management 2010-2025' www.moe.gov.al

[2] Andrea, V. (2015) Modern methods in solid waste management. In: Environmental Policy: Theory and Practice, Volume in honor of Alkiviadhs Dervitsiotis, Department of Forestry \& Management of the Environmental \& Natural Resources, Democritus University of Thrace, pp. 7-17.

[3] Eurostat, April 2015

[4] Hanan, D. Burnley, S., \& Cooke, D. (2013) A multi-criteria decision analysis assessment of waste paper management options. Waste Management, 33:3, 566-573.

[5] Ministry of Public Works, Transport and Telecommunication, 2012: 'Waste generation data' http://www.mppt.gov.al

[6] UNECE, 2012: 'Albania - Environmental performance reviews - Second review' http://www.unece.org/fileadmin/DAM/env/epr/epr_studies/Albaniall.pdf

[7] Rentizelas, A.A., Tolis, A.I., \& Tatsiopoulos, I.P. (2014) Combined Municipal Solid Waste and biomass system optimization for district energy applications. Waste Management, 34:1, 36-48.

[8] Marconsin A.F., \& Rosa, D.d.S. (2013) Comparison of two models for dealing with urban solid waste: Management by contract and management by public-private partnership. Resources, Conservation and Recycling, 74, 115- 123.

[9] Morrissey, A.J., \& Browne, J. (2004) Waste management models and their application to sustainable waste management. Waste Management, 24:3, 297-308.

[10] Wapner P. (2002). Ecological Displacement and Transnational Environmental Justice, Global Dialogue, Vol 4, No. 1, Winter 2002, The Fragile Biosphere, http://www.worlddialogue.org/content.php?id=178 